\title{
Retinol-Binding Protein 4
}

National Cancer Institute

\section{Source}

National Cancer Institute. Retinol-Binding Protein 4. NCI Thesaurus. Code C138098.

Retinol-binding protein 4 (201 aa, $23 \mathrm{kDa}$ ) is encoded by the human RBP4 gene. This protein plays a role in retinol transport. 